\title{
MODERN TATAR FINE ARTS AS MEANS OF ETHNOCULTURAL EDUCATION
}

\author{
Guzel R. Nasibullova \\ Kazan (Volga region) Federal University, 420008, Kazan, Russia \\ guz1983@mail.ru \\ Rasykh F. Salakhov \\ Kazan (Volga region) Federal University, 420008, Kazan, Russia \\ Ramis R. Nasibullov \\ Kazan (Volga region) Federal University, 420008, Kazan, Russia
}

\begin{abstract}
The topicality of the problem under study is justified by the increased attention to studying, preservation, revival and development of the traditional culture, to a wide extent caused by the growth of ethnic consciousness of the people. The study is aimed onto the investigation of the potential of modern Tatar fine arts as a part of ethnocultural education. Ethnocultural education includes preservation and revival of the national culture and traditions of people and their ethnocultural identity by means of familiarizing with the mother-tongue and culture, as well as studying the values of the world culture. Art is a necessary condition and means of ethnocultural education of students, as it represents the world of images surrounding them in natural and social reality, and creates an emotionally rich environment for the formation of their own worldview. Fine arts promote expansion of national culture and history knowledge among modern youth. In modern Tatar national fine arts we can observe interest in development of various rafts of art heritage, and national culture in general.
\end{abstract}

Keywords: ethnocultural education, fine arts, people, nationality, tradition.

\section{INTRODUCTION}

Nowadays the interaction of people leads to evanescence of interethnic borders, interethnic variety disappears, and on the other hand an interethnic intensity emerges. Therefore, the formation of interethnic tolerance in modern youth is very important. Working-out a certain way of development and improvement of pedagogical activity in a multiethnic and polycultural environment is among top-priority tasks of modernization of Russian educational system. Humanization of the society, which has proclaimed the person to be the highest value, needs humanitarian, esthetic and ethical means promoting spiritual development of the inward man [Gogoleva, 2005].

This problem can be solved effectively due to ethnocultural education of children on the basis of the principle of a dialogue of cultures, promoting harmonization of the international relations, spiritual consolidation of people. However, the use of potential of national art in formation of ethnocultural knowledge of modern youth is realized insufficiently.

One of the means to increase efficiency of ethnocultural education is fine arts. Fine arts' perception becomes a condition of adequate acquisition of ethnic and world culture values, in general, patriotic education, cultural tolerance and awareness.

\section{MATERIALS AND METHODS}

In the course of the research the following approaches and methods were used: a system approach for revealing insights of the problem, classification, systematization, synthesis of the pedagogical experiment on the problem under study; supervision, comparison, questioning, analysis of the received results, processing of experimental data, etc.

\subsection{Research foundation}


State and public organizations, such as Institute of Philology and cross-cultural Communication (named after Leo Tolstoy) of the Kazan (Volga region) Federal University.

\section{RESULTS}

The results of the research show that introducing to educational process the following concepts: national culture, norms of social behavior, spiritual and moral values, cultural achievements of the other people; and the use of experience of national education arises interest of modern youth in national culture, forms a friendly attitude towards people of different nationalities. This research paper practically helps the research workers to deal with the problems of ethnocultural education, theory and history of the Tatar art.

\section{DISCUSSIONS}

A considerable number of the researches is devoted to various aspects of ethnocultural education. At different times the following researchers addressed the problem of ethnocultural education [Likhachev, 2007; Tieclt, Tiedt, 1995; Aspinall, 2004; Lin, 2011; Poshtareva, 2008]. The fundamental works on the theoretical basis of the analysis of the modern Tatar fine arts and detection of its importance in educational process are the ones of G.F. Valeeva-Suleymanova (1993), S.M. Chervonnaya (2008), R. Shamsutov (1997), etc. The analysis of the recent researches on ethnocultural education of students shows that, despite theoretical and practical importance of the modern techniques of fine arts education, they reflect rather narrow aspects of the problem. These aspects are mainly connected with the development of certain means, forms, methods of training and education.

The topicality of the studied subject is defined by the requirements of the education system and the contradictions between:

- the need of theoretical judgment of ethnocultural potential of fine arts and decrease of interest towards it from family and teachers;

- the need of knowledge of the process of ethnocultural education of the personality at all stages of its development and a lack of theoretical and practical studies on the subject matter of the process in relation to modern youth;

- the potential of fine arts in ethnocultural education of students and a lack of specially developed pedagogical conditions for its realization.

\section{MAIN PART}

The concept of "ethnocultural education" is a new approach appeared at the end of the XX century. Today it plays an active role in pedagogical science, but there's still no single understanding of it. The concept of "ethnocultural education" is used along with such terms as "ethnonational", "ethnoregional", "national and regional", "polycultural" education.

To become a citizen and a patriot, knowing and loving his Homeland, the small homeland, its people, a child throughout his education needs to get to know the spiritual riches of the people as well [Roads, 2003]. One of the features of the national culture in a constantly changing reality and the way of public life is its stablity and not being a subject to radical transformation. Therefore, ethnoculture is both a source of updating of a substantial basis of modern education and traditional ethnic means of the formation of the personality [Rooijen, 2003]. The knowledge of sources of people's art, its nature and spiritual value is an integral part of spiritual culture of the person.

According to the Federal state educational standard of the general education, which has been developed taking into account regional, national and ethnocultural requirements of the people of the Russian Federation, the idea of preservation and cultural development of our country is top-priority and widespread in a modern educational system [Zamaletdinov+et al, 2015; Yarmakeev+et al, 2014].

The national and regional component in the contents of art education standard includes knowledge of historical and cultural traditions of the region, of art, both national and professional, and its brightest representations. The specific of development of each region, national and cultural traditions of its people defines the uniqueness of the contents of the art education regional component [Akhmetshina, 2000]. 
Nowadays the cultural space of educational institution becomes an ambience where adults set examples of behavior, activity, self-assessment, and worldview. Modern conditions demand such a space that would meet all the requirements of time, but wouldn't tear off the person from his roots at the same time.

Spiritual and moral education of youth on the basis of ethnocultural traditions will be effective if:

- students acquire humanistic values on the principles of national idea and universal moral values throughout educational process;

- the ethnic component of spiritual and moral education content stimulates the development of the idea of belonging to the ethnoculture and its position among other ethnic cultures;

- students assimilate ethnocultural traditions along with the development of an ability to understand themselves and other people as a part of the ethnoculture;

- students are engaged in various kinds of activities that becomes a starting point for activity development of the national culture space.

Ethnocultural component is understood as everything that promotes development of creative potential of the student, gives a better understanding of richness of national culture, tenor of life, history, language, literature, spiritual purposes and values of people. All this promotes the development of an all-round personality, a patriot of the Homeland, a highly moral and tolerant individual [Yusupova+et al, 2015]. The ethnocultural perspective is very complex, but inspite of the fact that the sciences studying ethnical problems are going forward, a considerable amout of its concepts are still insufficiently developed. Some certain areas of the ethnoculture are an object of research of many other sciences: various branches of ethnology, folklore studies, art criticism, ethnopedagogics, ethnopsychology, etc [Bolshakov, 1969]. Fine arts as one of the elements of national art, expressing both history and the present, play a very special role in ethnocultural education. Nowadays we can observe a rising tide of interest in national culture, to a great extent caused by the growth of ethnic consciousness of the people.

Art, as one of the accumulators and sources of culture, plays a special role in the course of ethnocultural education, owing to an available international language - the language of artistic images. It has no communicative national borders and can be freely used as a factor of the person's entry into ethnic and world culture [Petrov, 2015]. Art acts as a mediated face of mankind, and those who perceive art, enter communication with another people having some certain social experience. Thanks to its peculiar impact on a person (sensual spontaneity, emotional saturation, incentive force, uplift, esthetic pleasure), art can carry out a very important function of education and it is one of the most important components of the spiritual culture of an individual [Kagan, 2000]. Modern artists try to reflect deep sources of cultural, historical and spiritual heritage of Tatar people in their works. The modern Tatar fine arts is based on centuries-old space of traditions where the East meets the West. The Turkic idea, resulting from recognition of common ethnic origin, kinship of the language and Turkic peoples cultural proximity, becomes actual as well. We can observe a resolute break of national public consciousness towards the discovery of the historical heritage all over again - new versions of the Tatar ethnogenesis move forward, interest in traditional culture of the Tatar people arises [Valeeva-Suleymanova, 1998].

Tatar cultural, historical and spiritual heritage becomes an inspiration source for works of many modern artists. For example, S. Shaydullin, F.Yakupov, etc. try to reflect the fading traditional way of living adjoining to the rhythms of modern life, U. Abdulov, F.Khalikov demonstrate the Tatar culture in the form of historical reconstructions. The idea of national renaissance expresses itself, first of all, in revival of national traditions that were decisively influenced by ethics and esthetics of Islam. The religion acts as one of the factors of ethnic consciousness of the Tatar people. The modern Tatar artists pay a lot of attention to Islam as well; it inspires them with its metaphoricalness, mysticism, tremendous decorative effect. Inspired by Koranic images and motives many artists gave special expressiveness to their works. A good example is the works of A. Ilyasova. A. Ilyasova has brought a number of mythological images, taken from the Koran, hadiths (a report describing the words, actions, or habits of the Prophet Muhammad), national beliefs into the language of the modern Tatar art; her works are musical, rhythmic, decorative, they show a grandiose victory of free consciousness, celebration of the Kazan orientalism.

Revival of traditional types of the Islamic art enriches the Tatar national art with new paints and styles. Art of the hand-written book - calligraphy in a wide variety of traditional handwritings is inseparably linked 
with Islam in art culture of the Tatar Bulgars. One of the types of the Tatar art creativity «shamail» (a peculiar phenomenon of Muslim culture, important part of religious and esthetic consciousness, type of the fine arts; a panel painting executed in ink printed oil paints on glass or a canvas embroidered on a cloth) is closely connected with a calligraphical tradition. For the Volga Tatars shamail is a wall inscription of a usually rectangular horizontal form containing a calligraphical text - a saying from the Koran. Shamail is an integral part of an interior of each Tatar house, mosque. Now the revival of shamail is observed. Such artists as F. Girfanov, N. Ismagilov pay a special attention to calligraphic and graphic shamail in their creativity.

Landscapes with architectural monuments of Bulgar and Kazan play an important role in F. Girfanov's creativity. His landscapes are invented much of what the artist has represented, is an assumption. He seeks to restore the past, the spiritual condition of the modern Tatar society, captured by a rush of ethnic selfaffirmation. Shamails of F. Girfanov are also philosophical narrations about basic provisions of the doctrine of Islam, its role in the history, and life of the Tatar people. Nazhip Ismagilov's creativity differs from the contemporaries, as the foreground is given to shamails. In his shamails, tugrakhs (calligraphical signs, symbols of certain people) N. Ismagilov uses not only the Koranic text, but also a secular syllable - excerpts from works of the famous Tatar poets like Qol Ghali, Akmulla, Gali Choqryi, poetry of the Muslim East, folklore narrating about human virtue, morality. Ismagilov's works differ in use of not only letters of the Arab alphabet, but also Latin, and Cyrillics. He has created a series of tughras.

For identification of awareness of the youth about the history, traditions and ethnoculture of the Tatar people we have conducted a mass experiment. 300 people of different occupation at the age of 18-25 years participated in the experiment. It was offered to each examinee to answer a set of questions on 10 pictures of the modern Tatar artists devoted to the history, tradition, and culture of the Tatar people. The examinees had to call the objects, symbols, colors, connected with ethnoculture of the people, historical events and persons represented in the pictures. The following questions have been asked: 1 . When were you at a fine arts exhibition for the last time? 2. What elements of the Tatar ethnoculture can you enumerate? 3. Can you name any modern Tatar artists? 4. Do you know any pictures devoted to the Tatar national culture? 5. If you painted a picture on the Tatar national culture, what would you depict? The purpose of the questionnaire was identification of the attitude of the youth to the modern Tatar fine arts and the level of thier knowledge in this field. The examinees answered the questions about the elements of national clothes, life, national holidays and customs correctly. But it has become clear that they do not possess enough knowledge of historical events and persons of the Tatar people. The results of the poll are presented in the following chart.

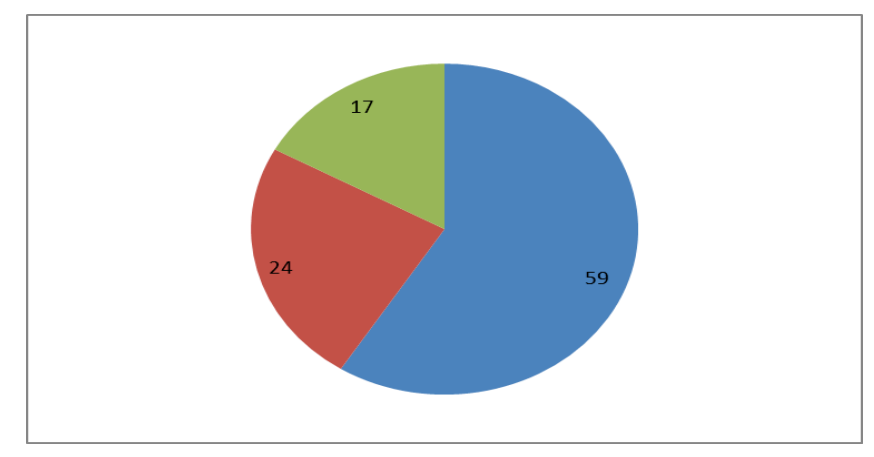

According to the results of the poll, $83 \%$ of the interrogated people have shown a high and average level of knowledge in the field of art. They are interested in history, culture, traditions of the Tatar people, observe the development of the modern Tatar national art. Meanwhile, the analysis of the answers has shown that there are people among the youth who are unfamiliar with art. $17 \%$ of the respondents have very little knowledge in the field of history and culture of the Tatar people.

\section{SUMMARY}

The short review of the modern Tatar fine arts shows the versatility of works of modern artists. Using different art systems, different "historical" languages, the modern Tatar artists embody history, ethnic roots, traditions, values of the people in their pictures. In kaleidoscopical speed of events, at fragility of human and social communications, we all need a support in the form of eternal values, consciousness of moral guidelines. And artists see the stability of life in naturalness of the way of the rural life, great depth of bible and Koranic truth, in harmony of the nature. 


\section{CONCLUSION}

Getting to know national culture has to be fundamental throughout the education process, as the best creative achievements of the people are fixed in them. Following the results of our research, it has been revealed that art exerts a huge impact on a spiritual condition of the person, its ability to creativity, its lifestyle and outlook. Art, according to our opponents, is the most important in the development of a feeling, esthetically well-mannered and susceptible personality.

\section{Acknowledgments}

The research is performed according to the Russian Government Program of Competitive Growth of Kazan Federal University.

\section{REFERENCES}

Gogoleva, S.A., 2005. The fine arts as means of ethnoculturological education of pupils of the 5-9th grades (on the example of the Republic of Sakha (Yakutia)): thesis, Cand.Sc. Yakutsk, 184 p.

Likhachev, B.T., 2007. National idea and content of civil education // Pedagogics, No. 9, P. 60-65.

Tieclt, Pamela L., Tiedt, Iris M., 1995. Multicultural Teaching: A Handbook of activities, information, and resources, Boston Allyn and Bacon.

Aspinall, P., 2000. The Challenges of Measuring the Ethno-Cultural Diversity of Britain in the New Millennium // Policy and Politics, Vol. 28, No. 1, P. 114.

Lin, J., 2011. The Power of Urban Ethnic Places: Cultural Heritage and Community Life. Taylor\&Francis. The Metropolis and Modern Life, New York.

Poshtareva, T.V., 2008. Education with based on national traditions // Elementary school before and after, No. 10, P. 9-11.

Valeeva-Suleymanova, G.F., 1993. National culture of Tatarstan: ways of revival // Tatarstan, No. 12, P. 4752.

Chervonnaya, S.M., 2008. Art and religion. Modern Islamic art of the people of Russia. M: ProgressTradition, $552 \mathrm{p}$.

Shamsutov, R., 1997. Shamail with the names of inhabitants of the cave and its magic properties // The Kazan oriental studies: traditions present and prospects. Kazan, P. 156.

Roads, R., 2003. Globalizition of education and student activist // Higher Education. Vol. 45, No. 3. P. 48.

Rooijen, M., 2003. The emergence of global and multinational universities // EAIE Occasional, P. 15.

Zamaletdinov, R.R., Zamaletdinova, G.F., Sibgaeva, F.R., 2015. Reflection of Tatar inner world through concepts // Journal of Language and Literature, No. 3, P. 115-118.

Yarmakeev, I.E., Pimenova, T.S. 2014. The formation of students' national self-awareness in EFL class // English Language Teaching, Vol 7, No. 12, P. 26-35.

Akhmetshina, A.K., 2000. Current trends of the Tatar fine arts: abstract of a thesis, Ph.D.in art history. M, 24 p.

Yusupova, A.S., Galiullina, G.R., Denmukhametova, E.N., 2014. Representation of national mentality in Turkic-Tatar vocabulary // Life Science Journal, Volume 11, Issue 7, P. 506-508.

Bolshakov, O., 1969. Islam and fine arts // Works of the State Hermitage. T.K.L., P. 142-156.

Petrov, N.E., 2015. Variety of Aspects of Researches of Graphic Activity as Pedagogical Problem // Mediterranean Journal of Social Sciences, Vol 6, No. 1, P. 96-98.

Kagan, M.S., 2000. Art Studies and Art Criticism: Chosen articles. SPb., P. 195-199.

Valeeva-Suleymanova, G.F., 1998. A typology of interaction of art culture of Tatars in the East West system. Kazan: Institute of history, TATARICA No. 1, P. 108-128. 